\title{
Incorporation of Omega-3 Fatty Acid and Synthesis of their Metabolites in Muscle Tissue in Mice Fed with Flaxseed and Perilla-Enriched Diet
}

\author{
${ }^{1}$ Sheisa Cyleia Sargi, ${ }^{2}$ Flavia Braidotti Stevanato, \\ ${ }^{3}$ Marcia Machado de Oliveira Dalalio, ${ }^{2}$ Damila Rodrigues de Morais, \\ ${ }^{3}$ Amarilis Giaretta de Moraes, ${ }^{3}$ Jeane Eliete Laguila Visentainer and ${ }^{2}$ Jesui Vergilio Visentainer \\ ${ }^{1}$ Department of Agricultural Sciences-Food of Science, State University of Maringá, Paraná, Brazil \\ ${ }^{2}$ Department of Chemistry, State University of Maringá, Maringá, Paraná, Brazil \\ ${ }^{3}$ Department of Basic Health Sciences, State University of Maringá, Maringá, Paraná, Brazil
}

Received 2012-11-21, Revised 2012-12-10; Accepted 2013-05-04

\begin{abstract}
Polyunsaturated fatty acids omega 3 and omega 6 are believed to have beneficial physiological effects on the human body. The present study aimed to evaluate the incorporation and synthesis of omega- 3 fatty acid and their metabolites in muscle tissue in mice fed with a flaxseed and perilla-enriched diet. The animals were fed a diet supplemented with flaxseed and perilla meals for fifty-six days and control animals received a commercial diet. Mice were sacrificed on the 7th, 28th and 56th days and the muscle tissue was collected. The FA concentration was analyzed by gas chromatography. The levels of alpha-Linolenic Acid (LNA) and their metabolites, Eicosapentaenoic Acid (EPA) and Docosahexaenoic Acid (DHA) increased as a function of feeding length in the groups given the supplemented diet. LNA was incorporated into muscle tissue and conversion into Very Long Chain Polyunsaturated Fatty Acids (VLC-PUFA) was observed. The muscle tissue of animals fed with enriched diets presented a high sum of $n-3$ FA and high concentrations of LNA, EPA and DHA, as compared to mice fed commercial diet. The intake of flaxseed and perilla-meal enriched diets by mice may result in the deposition of LNA and its metabolites EPA and DHA into muscle tissue.
\end{abstract}

Keywords: Incorporation, Omega-3, Omega-6, Supplementation, Mice

\section{INTRODUCTION}

Alpha Linolenic Acid (LNA, 18:3n-3) and Linoleic Acid (LA, 18:2n-6) are strictly Essential Fatty Acids (EFA). Because they are not produced by mammals, including human beings, they must be obtained through the diet or by supplementation (Perini et al., 2010). Once consumed, they are metabolized by the same sequential desaturation and elongation enzyme systems, which results in the production of Long Chain Polyunsaturated Fatty Acids (LC-PUFAs) of the n- 3 and n- 6 series. LA is found in high concentrations in various vegetable oils, such as soy, sunflower and corn oils. Flaxseed (Linum usitatissimum) and perilla (Perilla frutescens) are the richest known sources of alpha-Linolenic Acid (LNA, 18:3n-3), a precursor of the long chain n-3 PUFA series (Roberfroid, 2002; Asif, 2011).

The conversion of LNA and LA into their longer chain homologues occurs by a combination of subsequent reactions involving $\Delta 6$ desaturation of LNA to $18: 4 n-3$ and of LA to $18: 3 n-6$, followed by elongation and $\Delta 5$ desaturation to Eicosapentaenoic Acid (EPA, 20:5n-3) and arachidonic acid (AA, 20:4n-6). Final elongation and $\Delta 4$ desaturation produces Docosapentaenoic Acid (DPA, Corresponding Author: Jesui Vergilio Visentainer, Department of Chemistry, State University of Maringá, Maringá, Paraná, Brazil Tel: +55 (44) 3011-3663 Fax: +55 (44) 3263-5784 
22:5n-6) and Docosahexaenoic Acid (DHA, 22:6n-3) (Kim, 2007). This conversion takes place in the endoplasmic reticulum, especially in liver cells (MacDonald-Wicks and Garg, 2007).

AA is important for fetal growth and the metabolism of prostaglandins (Innis, 2007). Among the LC-PUFA, EPA and DHA have received much attention from the scientific community because of their positive role in human health (Wurtman, 2008). Numerous health benefits have contributed to the popularity of n-3 PUFA. In general, increased dietary $n-3$ PUFA intake promotes retina and brain development in infants; in adults, $n-3$ PUFA consumption has been reported to reduce the risk of cardiovascular disease, obesity, diabetes, inflammation, cancer and to improve immunity (Calder et al., 2009; Ratnayake and Galli, 2009). Deckelbaum et al. (2006) reported that increasing tissue levels of $n-3$ PUFA exerts beneficial physiological effects by influencing cell membrane fluidity, membrane-bound receptors, signaling molecules and gene expression.

The dietary level of n-3 FA may be changed by the concomitant intake of other types of fats and n- 6 and n-3 FA are known to compete for elongation and desaturation. This competition for $\Delta 6$ desaturase affects the incorporation of n-3 LC-PUFA metabolites by tissues and thus the impact of n-3 LC-PUFA on chronic diseases (James et al., 2000).

Studies have shown that the distribution of EFA is modulated by dietary intake and that food manipulation can directly influence property regulations, such as the formation of eicosanoids (Wallace et al., 2003). Eicosanoid acids are oxygenated metabolites of EFA originated from AA and EPA. They are components of prostaglandins, leukotrienes, thromboxanes and prostacyclins, which participate in many infectious processes. Moreover, they are also involved in the reproductive function, platelet formation and regulation of blood pressure, gastric acid secretion and a variety of other processes important to human health (Bagga et al., 2003).

ALA, EPA and DHA are believed to have beneficial physiological functions and, therefore, are important to understand the metabolism of LNA in mammals, which grants the interest in the metabolism of PUFA. Thus, experimental studies are sorely needed, so the aim of this work was evaluated the levels of incorporation in muscle tissue of mice fed with flaxseed and perila-enriched diet for 56 days.

\section{MATERIALS AND METHODS}

\subsection{Animals and Experimental Design}

Ninety four-week-old male Swiss mice were provided by the central animal house of the State University of Maringa. A 12-h dark/12-h light cycle and a room temperature of $23 \pm 1^{\circ} \mathrm{C}$ were maintained. The animals received food and water ad libitum. After acclimatization for 7 days, 30 animals were randomly assigned to each of three groups according to the experimental diet: Control Group (CG), Flaxseed Group (FG) or Perilla Group (PG) and were kept in polycarbonate cages. In order to evaluate the incorporation of fatty acid omega-3 in muscle tissue, ten mice of each group were sacrificed on the $7 \mathrm{th}, 28 \mathrm{th}$ and 56th days and paw muscle tissue was removed and kept in polyethylene bags in $\mathrm{N}_{2}$ atmosphere at $-18^{\circ} \mathrm{C}$ until analysis. At the beginning of each analysis, the tissue samples were allowed to equilibrate to room temperature, diced and homogenized. The level of fatty acids in the tissue was evaluated. This study was approved and conducted according to the guidelines of the Ethics Committee for Animal Research of State University of Maringa (No. 007-2011).

\subsection{Diets}

Experimental diets were designed according to the NRC (1995). The experimental diets were nutritionally complete (isocaloric, isoproteic and normolipidic). The basic diet composition is shown in Table 1. Enriched diets were pelleted and prepared in bulk, separated in daily portions, vacuum packed and stored at $4{ }^{\circ} \mathrm{C}$ for a maximum period of 1 week to prevent fatty acid oxidation. Total lipids and fatty acid composition of total lipids of freshly prepared diets were monitored.

\subsection{Total Lipids and Fatty Acid Composition}

Total Lipids (TL) in tissues and feed were determined according to Bligh and Dyer (1959). Fatty Acid Methyl Esters (FAME) were prepared by methylation of total lipids following Joseph and Ackman (1992). The methyl esters were separated by gas chromatography using a Varian 3300 (USA) gas chromatograph fitted with a flame ionization detector and a fused-silica CP-select CB-Fame capillary column (100 $\mathrm{m} \times 0.25 \mathrm{~mm}$ i.d., $0.25 \mu \mathrm{m}$ cyanopropyl CP-7420) operated at a detector temperature of $240^{\circ} \mathrm{C}$ and injection port temperature of $240^{\circ} \mathrm{C}$. The column temperature was maintained at $165^{\circ} \mathrm{C}$ for $12 \mathrm{~min}$ and programmed to rise from 165 to $185^{\circ} \mathrm{C}$ at $40^{\circ} \mathrm{C} / \mathrm{min}$ for $15 \mathrm{~min}$ and from 180 to $240{ }^{\circ} \mathrm{C}$ at $15^{\circ} \mathrm{C} / \mathrm{min}$ in $18 \mathrm{~min}$. 
Table 1. Composition, total lipid content and fatty acid composition of the experimental diets

\begin{tabular}{|c|c|c|c|}
\hline Ingredients $(\% \mathrm{w} / \mathrm{w})$ & Control diet & Flaxseed meal-enriched diet & Perilla meal-enriched diet \\
\hline Flaxseed meal & $\begin{array}{ll}--- \\
--\end{array}$ & 10 & ---- \\
\hline Perilla meal & ---- & ---- & 7 \\
\hline Soybean meal & 38.74 & 32.09 & 28.4 \\
\hline Wheat meal & 11.48 & 9.63 & 31.58 \\
\hline Ground corn & 42.71 & 40.78 & 23.54 \\
\hline Dicalcium phosphate & 20.35 & 2.7 & 3.07 \\
\hline Sodium chloride & 0.3 & 0.3 & 0.3 \\
\hline Premix & 4.5 & 4.5 & 4.5 \\
\hline Composition & Means \pm SD & Means $\pm \mathrm{SD}$ & Means \pm SD \\
\hline Total Lipids (\%) & $6.5 \pm 1.15$ & $6.2 \pm 0.4$ & $6.8 \pm 1.4$ \\
\hline \multicolumn{4}{|l|}{$\begin{array}{l}\text { Fatty acid } \\
(\mathrm{mg} / \mathrm{g} \text { total lipids })^{\mathrm{a}}\end{array}$} \\
\hline $16: 00$ & $127.8 \pm 0.23^{\mathrm{a}}$ & $83.2 \pm 2.8^{\mathrm{c}}$ & $101.8 \pm 1.67^{\mathrm{b}}$ \\
\hline $17: 00$ & $0.7 \pm 0.02$ & $0.6 \pm 0.3$ & nd \\
\hline 18:00 & $26.5 \pm 0.12^{\mathrm{a}}$ & $33.5 \pm 1.6^{\mathrm{a}}$ & $16.9 \pm 0.26^{\mathrm{b}}$ \\
\hline $18: 1 n-9$ & $211.5 \pm 0.69^{\mathrm{a}}$ & $181.0 \pm 2.3^{\mathrm{c}}$ & $152.4 \pm 2.05^{\mathrm{b}}$ \\
\hline $18: 1 n-7$ & $9.7 \pm 0.03$ & $18.6 \pm 1.8$ & $9.5 \pm 0.11$ \\
\hline $18: 2 n-6(L A)$ & $422.7 \pm 1.75^{\mathrm{a}}$ & $254.1 \pm 2.2^{\mathrm{b}}$ & $265.2 \pm 1.38^{\mathrm{b}}$ \\
\hline $18: 3 n-6$ & $0.2 \pm 0.29$ & $0.8 \pm 0.2$ & nd \\
\hline $18: 3 n-3$ (LNA) & $34.5 \pm 0.08^{\mathrm{a}}$ & $260.2 \pm 2.5^{\mathrm{b}}$ & $310.7 \pm 1.80^{\mathrm{b}}$ \\
\hline $20: 00$ & $2.9 \pm 0.01^{\mathrm{a}}$ & $7.6 \pm 1.3^{\mathrm{c}}$ & $1.7 \pm 0.01^{\mathrm{b}}$ \\
\hline $20: 1 n-9$ & $3.4 \pm 0.02^{\mathrm{a}}$ & $0.4 \pm 0.1^{\mathrm{c}}$ & $2.5 \pm 0.07^{\mathrm{b}}$ \\
\hline MUFA & $222.7 \pm 0.36^{\mathrm{a}}$ & $201.2 \pm 2.1^{\mathrm{a}}$ & $136.1 \pm 1.06^{\mathrm{b}}$ \\
\hline SFA & $157.9 \pm 0.21^{\mathrm{a}}$ & $124.3 \pm 1.0^{\mathrm{b}}$ & $120.3 \pm 0.95^{b}$ \\
\hline PUFA & $464.0 \pm 0.87^{\mathrm{a}}$ & $514.2 \pm 0.8^{\mathrm{b}}$ & $577.3 \pm 0.97^{\mathrm{b}}$ \\
\hline$n-6$ & $422.9 \pm 1.75^{\mathrm{a}}$ & $254.1 \pm 1.9^{\mathrm{b}}$ & $266.6 \pm 0.99^{b}$ \\
\hline$n-3$ & $34.5 \pm 0.08^{\mathrm{a}}$ & $260 \pm 1.7^{\mathrm{b}}$ & $310.7 \pm 1.80^{\mathrm{b}}$ \\
\hline PUFA/SFA & $2.9 \pm 0.05$ & $4.1 \pm 0.4$ & $8.3 \pm 0.02$ \\
\hline$n-6 / n-3$ & $12.2 \pm 0.03^{\mathrm{a}}$ & $0.9 \pm 0.3^{\mathrm{b}}$ & $0.9 \pm 0.05^{\mathrm{b}}$ \\
\hline
\end{tabular}

PUFA $=$ Polyunsaturated Fatty Acid, MUFA $=$ Monounsaturated Fatty Acid, SFA $=$ Saturated Fatty Acid, $n-6=$ Omega- 6 fatty acid, $n-3=$ Omega- 3 fatty acid. Results expressed as mean \pm standard deviation for analysis in nine replicates. $\mathrm{N}=10$. Means followed by different letters in the same line are significantly different $(\mathrm{P}<0.05)$ by Tukey's test and test $\mathrm{t}$. Control diet versus flaxseed and perilla meal-enriched diets. $\mathrm{nd}=$ not detected.

The ultra-pure gas flows were: $1.4 \mathrm{~mL} \cdot \mathrm{min}^{1}$ carrier gas (hydrogen), $30 \mathrm{~mL} \cdot \mathrm{min}^{-1}$ make-up gas (nitrogen), 300 mL. min $^{-1}$ synthetic air and $30 \mathrm{~mL} \cdot \mathrm{min}^{-1}$ hydrogen flame gas, split injection, 1:100 ratio (injection in triplicate). Retention times and peak area \% values were automatically computed by a Varian 4290 integrator. For the identification of FA, FA retention times were compared to those of standard methyl esters (Sigma, USA).

\subsection{Quantification of Fatty Acid Methyl Esters (FAME)}

The concentration of FA in $\mathrm{mg} . \mathrm{g}^{-1}$ of total lipids in paw muscle tissue was measured against tricosanoic acid methyl ester (23:0) from Sigma (USA) as an internal standard, as described by Joseph and Ackman (1992) and Visentainer (2012). The following formula was used to calculate the concentrations: $\mathrm{FA}\left(\mathrm{mg} \mathrm{g}^{-1} \mathrm{TL}\right)=\left(\mathrm{A}_{\mathrm{X}} \mathrm{x} \mathrm{W}_{\mathrm{IS}}\right.$ $\left.x \mathrm{CF}_{\mathrm{X}}\right) /\left(\mathrm{A}_{\mathrm{IS}} \times \mathrm{W}_{\mathrm{X}} \times \mathrm{CF}_{\mathrm{AE}}\right)$, where TL is total lipids, $\mathrm{Ax}$ is the peak area of fatty acids, $\mathrm{A}_{\mathrm{IS}}$ is the peak area of the Internal Standard (IS) tricosanoic acid methyl ester (23:0), $\mathrm{W}_{\mathrm{IS}}$ is the weight (mg) of IS added to the sample (in $\mathrm{mg}$ ), $\mathrm{W}_{\mathrm{X}}$ is the sample weight (in $\mathrm{mg}$ ), $\mathrm{CF}_{\mathrm{X}}$ is the theoretical correction factor and $\mathrm{CF}_{\mathrm{EA}}$ is the correction factor of methyl ester for fatty acids.

\subsection{Statistics}

The mean values were statistically compared by Tukey's test and test $t$ at $5 \%$ with one-way ANOVA. Data were processed using Statistica 7.0 software.

\section{RESULTS}

No significant differences in body weight were observed between the diet groups in the 56 days of experiment. The mean body weight values were: $\mathrm{CG}$ $47.58 \pm 4.27 \mathrm{~g}, \mathrm{FG} 42.10 \pm 4.18 \mathrm{~g}$ and PG $46.09 \pm 5.2 \mathrm{~g}$. 
The TL and FA composition of the diets are presented in Table 1. The TL values were $6.5 \%$ for control diet, $6.2 \%$ for flaxseed meal-enriched diet and $6.8 \%$ for perilla meal-enriched diet.

The quantitative analysis of FA in the diets and paw muscle tissue are expressed in $\mathrm{mg}$ of FA per gram of total lipid (mg. $\left.\mathrm{g}^{-1} \mathrm{TL}\right)$ and are presented in Table 1 and 2, respectively. The major FA in both experimental diets were palmitic acid (16:0) and oleic acid (18:1n-9). The control diet had the highest amount of linoleic acid (422.73 mg. $\left.\mathrm{g}^{-1} \mathrm{TL}\right)$ and the flaxseed and perilla mealenriched diets had the highest amounts of alpha-linolenic acid, $260.2 \mathrm{mg} . \mathrm{g}^{-1} \mathrm{TL}$ and $310.7 \mathrm{mg} . \mathrm{g}^{-1} \mathrm{TL}$, respectively. These values were significantly different $(\mathrm{P}<0.05)$.
The LA level in tissue was higher in mice fed the control diet than the flaxseed and perilla meal-enriched diets due to its higher concentration of LA. The LA metabolites were 20:3n-6, 20:2n-6 and AA. AA was found in lower quantities in $\mathrm{FG}$ and $\mathrm{PG}$, when compared with CG. However, the levels in PG significantly decreased $(\mathrm{P}<0.05)$ from the 7 th $\left(14.2 \mathrm{mg} \cdot \mathrm{g}^{-1} \mathrm{TL}\right)$ to the 56th day (5.0 mg. $\left.\mathrm{g}^{-1} \mathrm{TL}\right)$.

The highest level of LNA was found in muscle tissue (FG and $\mathrm{PG}$ ) with a significant increase from the 7th day (41.9 mg. ${ }^{-1} \mathrm{TL}$ and $57.9 \mathrm{mg} \cdot \mathrm{g}^{-1} \mathrm{TL}$ ) to the 28th day $\left(60.4 \mathrm{mg} \cdot \mathrm{g}^{-1} \mathrm{TL}\right.$ and $\left.82.3 \mathrm{mg} \cdot \mathrm{g}^{-1} \mathrm{TL}\right)(\mathrm{P}<0.05)$, remaining on this level until the 56 th day $\left(58.9 \mathrm{mg}^{-1} \mathrm{~g}^{-1}\right.$

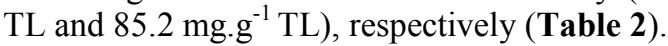

Table 2. Total lipids content and fatty acid composition of mice muscle tissue

\begin{tabular}{|c|c|c|c|c|c|c|c|c|c|c|}
\hline \multirow[b]{3}{*}{ Composition } & \multirow{3}{*}{$\begin{array}{l}\text { Control } \\
\text { group } \\
\text { Mean }\end{array}$} & \multicolumn{4}{|c|}{ Flaxseed group } & \multicolumn{5}{|l|}{ Perilla group } \\
\hline & & 7 days & 28 days & 56 days & & 7 days & 28 days & 56 days & & SD \\
\hline & & SD & Mean & Mean & Mean & SD Variation & Mean & Mean & Mean & Variation \\
\hline Total Lipids (\%) & 3.73 & 0.5 & $4.4^{\mathrm{a}}$ & $3.7^{\mathrm{b}}$ & $3.1^{\mathrm{b}}$ & $0.4-0.5$ & 4.6 & 2.7 & 3.1 & $0.07-1.28$ \\
\hline \multicolumn{11}{|c|}{ Fatty acids (mg FA/g TL) } \\
\hline $12: 00$ & 1.0 & 0.2 & $1.5^{\mathrm{a}}$ & $0.6^{\mathrm{b}}$ & $0.6^{\mathrm{b}}$ & $0.1-0.3$ & 2.80 & 1.1 & 0.6 & $0.01-0.1$ \\
\hline $14: 00$ & 9.2 & 1.1 & $11.7^{\mathrm{a}}$ & $8.6^{\mathrm{b}}$ & $6.7^{\mathrm{c}}$ & $0.6-0.9$ & 11.70 & 8.5 & 6.8 & $0.05-0.6$ \\
\hline $14: 1 n-9$ & 8.3 & 1.2 & 1.1 & 1.2 & 1.2 & $0.1-0.3$ & 0.90 & 0.7 & 0.9 & $0.04-0.1$ \\
\hline $15: 00$ & 1.5 & 0.2 & 1.3 & 1.2 & 1.3 & $0.2-0.3$ & $0.90^{\mathrm{a}}$ & $0.9^{\mathrm{a}}$ & $1.1^{\mathrm{b}}$ & 0.1 \\
\hline $15: \ln -5$ & 1.7 & 0.3 & 1.1 & 1.2 & 1.1 & $0.2-0.3$ & 1.90 & 1.7 & 1.7 & $0.1-0.2$ \\
\hline $16: 00$ & 177.0 & 6.3 & $200.8^{\mathrm{a}}$ & $187.7^{\mathrm{b}}$ & $156.3^{\mathrm{c}}$ & $1.1-5.1$ & 149.50 & 145.6 & 129.9 & $2.9-8.2$ \\
\hline $16: \ln -9$ & 5.2 & 0.3 & $4.0^{\mathrm{a}}$ & $5.5^{\mathrm{b}}$ & $5.6^{\mathrm{b}}$ & $0.1-0.4$ & $2.90^{\mathrm{b}}$ & $3.7^{\mathrm{b}}$ & $4.8^{\mathrm{a}}$ & $0.1-0.3$ \\
\hline $16: 1 n-7$ & 54.2 & 2.2 & 49.9 & 52.0 & 50.6 & $0.8-2.6$ & $35.30^{\mathrm{a}}$ & $42.9^{\mathrm{b}}$ & $50.7^{\mathrm{c}}$ & $0.8-3.1$ \\
\hline 17:00 & 1.4 & 0.2 & 1.3 & 1.4 & 1.4 & $0.1-0.3$ & 1.30 & 1.4 & 1.3 & $0.01-0.1$ \\
\hline $17: 1 n-5$ & 1.2 & 0.2 & 1.2 & 1.3 & 1.3 & $0.1-0.2$ & 1.20 & 1.7 & 1.8 & $0.1-0.2$ \\
\hline 18:00 & 38.9 & 3.9 & 36.1 & 41.8 & 40.1 & $1.2-3.3$ & $28.60^{\mathrm{a}}$ & $25.9^{\mathrm{b}}$ & $21.7^{\mathrm{c}}$ & $0.1-2.1$ \\
\hline $18: 1 n-9$ & 177.0 & 6.7 & 194.0 & 196.1 & 188.1 & $1.9-4.7$ & 169.30 & 169.2 & 180.0 & $1.4-5.3$ \\
\hline $18: \ln -7$ & 30.0 & 3.4 & 24.8 & 28.5 & 29.1 & $0.9-3.4$ & 14.40 & 13.5 & 14.3 & $0.3-1.5$ \\
\hline $18: 2 n-6$ (LA) & 239.0 & 4.6 & $208.4^{\mathrm{a}}$ & $187.1^{\mathrm{b}}$ & $176.7^{\mathrm{b}}$ & $1.7-3.1$ & 165.00 & 159.3 & 168.8 & $0.9-4.8$ \\
\hline $18: 3 n-6$ & 1.0 & 0.2 & 0.6 & 0.6 & 0.7 & $0.1-0.2$ & 0.47 & nd & nd & 0.07 \\
\hline $18: 3 n-3$ (LNA) & 10.5 & 0.9 & $41.9^{\mathrm{a}}$ & $60.4^{\mathrm{b}}$ & $58.9^{\mathrm{b}}$ & $0.8-2.6$ & $57.90^{\mathrm{b}}$ & $82.3^{\mathrm{a}}$ & $85.2^{\mathrm{a}}$ & $0.5-3.4$ \\
\hline $20: 00$ & 0.4 & 0.1 & 1.3 & 1.4 & 1.4 & $0.1-0.3$ & 0.50 & nd & nd & 0.5 \\
\hline $20: \ln -9$ & 2.4 & 0.3 & $2.3^{\mathrm{a}}$ & $2.1^{\mathrm{a}}$ & $1.7^{\mathrm{b}}$ & $0.4-0.6$ & $2.30^{\mathrm{a}}$ & $2.2^{\mathrm{a}}$ & $2.0^{\mathrm{b}}$ & $0.1-1.4$ \\
\hline $20: 2 n-6$ & 2.7 & 0.3 & 1.5 & 1.5 & 1.4 & $0.4-0.7$ & 1.70 & 1.1 & 1.3 & $0.002-0.1$ \\
\hline $20: 3 n-6$ & 3.0 & 0.4 & $2.7^{\mathrm{a}}$ & $2.5^{\mathrm{b}}$ & $2.2^{\mathrm{c}}$ & $0.4-0.7$ & $1.90^{\mathrm{ab}}$ & $1.7^{\mathrm{bc}}$ & $1.1^{\mathrm{c}}$ & $0.1-0.3$ \\
\hline $20: 4 n-6(\mathrm{AA})$ & 29.3 & 2.3 & 20.5 & 19.4 & 19.4 & $1.4-3.9$ & $14.20^{\mathrm{a}}$ & $9.6^{\mathrm{b}}$ & $5.0^{\mathrm{b}}$ & $0.3-2.2$ \\
\hline $20: 5 n-3$ (EPA) & 0.4 & 0.1 & $1.6^{\mathrm{a}}$ & $3.1^{\mathrm{b}}$ & $3.7^{\mathrm{b}}$ & $0.1-0.8$ & $4.10^{\mathrm{ab}}$ & $4.8^{\mathrm{a}}$ & $3.2^{\mathrm{ab}}$ & $0.01-0.1$ \\
\hline $24: 0$ & 3.9 & 0.3 & $2.4^{\mathrm{a}}$ & $1.1^{\mathrm{b}}$ & $1.0^{\mathrm{b}}$ & $0.3-0.6$ & 1.70 & 0.9 & nd & $0.03-0.1$ \\
\hline $22: 5 n-3$ & 4.3 & 0.4 & $4.4^{\mathrm{a}}$ & $10.1^{\mathrm{b}}$ & $13.1^{\mathrm{c}}$ & $0.2-0.4$ & $3.20^{\mathrm{ab}}$ & $4.8^{\mathrm{a}}$ & $4.1^{\mathrm{ab}}$ & $0.01-0.1$ \\
\hline $22: 6 \mathrm{n}-3$ (DHA) & 10.0 & 0.2 & $16.7^{\mathrm{a}}$ & $37.4^{\mathrm{b}}$ & $54.1^{\mathrm{c}}$ & $0.5-1.0$ & $10.70^{\mathrm{bc}}$ & $16.4^{\mathrm{a}}$ & $15.8^{\mathrm{ab}}$ & $0.1-0.3$ \\
\hline MUFA & 286.0 & 3.1 & $279.3^{\mathrm{a}}$ & $288.6^{\mathrm{a}}$ & $279.4^{\mathrm{b}}$ & $1.9-4.7$ & 227.40 & 235.7 & 255.5 & $1.5-7.6$ \\
\hline SFA & 235.0 & 3.0 & $256.4^{\mathrm{a}}$ & $243.8^{\mathrm{b}}$ & $208.8^{\mathrm{c}}$ & $1.8-4.8$ & $235.30^{\mathrm{a}}$ & $184.7^{\mathrm{b}}$ & $161.7^{\mathrm{b}}$ & $1.2-7.1$ \\
\hline PUFA & 300.0 & 4.1 & $297.0^{\mathrm{a}}$ & $322.1^{\mathrm{b}}$ & $330.2^{\mathrm{b}}$ & $1.1-3.3$ & $194.10^{\mathrm{b}}$ & $275.6^{\mathrm{a}}$ & $280.8^{\mathrm{a}}$ & $1.3-7.3$ \\
\hline$n-6$ & 275.0 & 4.0 & $233.7^{\mathrm{a}}$ & $211.1^{\mathrm{b}}$ & $200.4^{\mathrm{c}}$ & $1.3-3.3$ & 178.10 & 171.5 & 175.2 & $1.5-8.7$ \\
\hline$n-3$ & 25.2 & 1.5 & $63.3^{\mathrm{a}}$ & $111.0^{\mathrm{b}}$ & $129.8^{c}$ & $0.9-2.8$ & $16.00^{\mathrm{b}}$ & $103.9^{\mathrm{a}}$ & $105.5^{\mathrm{a}}$ & $1.3-5.2$ \\
\hline PUFA/SFA & 1.3 & 0.3 & $1.2^{\mathrm{a}}$ & $1.3^{\mathrm{a}}$ & $1.6^{\mathrm{b}}$ & $0.1-0.3$ & 0.80 & 1.5 & 1.7 & $0.004-0.04$ \\
\hline$n-6 / n-3$ & 10.9 & 0.4 & $3.7^{\mathrm{a}}$ & $1.9^{\mathrm{b}}$ & $1.5^{\mathrm{c}}$ & $0.3-0.7$ & $11.10^{\mathrm{a}}$ & $1.6^{\mathrm{b}}$ & $1.7^{\mathrm{b}}$ & $0.01-0.1$ \\
\hline
\end{tabular}

Total Lipids (TL), Fatty Acids (FA), Linoleic Acid (LA), Alpha-Linolenic Acid (LNA), Monounsaturated Fatty Acids (MUFA); Saturated Fatty Acids (SFA), Polyunsaturated Fatty Acids (PUFA), n-6 (omega- 6), n-3 (omega- 3). Mean values and standard deviations, $n=9$. Averages followed by different letters in the same line are significantly different $(\mathrm{P}<0.05)$ by Tukey's test and test t. Control group versus flaxseed and perilla groups. $\mathrm{nd}=$ not detected 
LNA metabolites (EPA and DHA) were identified in the three groups, CG, FG and PG. In the FG and PG groups, the synthesis of EPA was significantly higher ( $P$ $<0.05)$ than in the $\mathrm{CG}$ group. The DHA values were higher $(\mathrm{P}<0.05)$ in muscle tissue of mice fed FG and $\mathrm{PG}$ rather than $\mathrm{CG}$. The rate of incorporation of DHA increased significantly $(\mathrm{P}<0.05)$ on the 7 th day $(16.7$ mg. ${ }^{-1} \mathrm{TL}$ and $\left.10.7 \mathrm{mg} \cdot \mathrm{g}^{-1} \mathrm{TL}\right)$, when compared with the levels on the 56th day $\left(54.1 \mathrm{mg} . \mathrm{g}^{-1} \mathrm{TL}\right.$ and $15.8 \mathrm{mg}^{-\mathrm{g}^{-1}}$ $\mathrm{TL})$, respectively.

In relation to omega-6 FA, LA and AA levels were the highest in the CG muscle tissue; the values of LA did not change during perilla meal-enriched diet feeding; however the level of AA decreased during the experiment, specially on the 56th day $(\mathrm{P}<0.05)$ (Table 2). The reduction of the AA content following LNA dietary supplementation is well documented in the scientific literature (Brenna et al., 2009).

The sum of $n-3$ increased throughout the experiment in $\mathrm{PG}$ and FG and was higher on the 28th day (103.9 mg. $\mathrm{g}^{-1} \mathrm{TL}$ and $\left.111.0 \mathrm{mg} \cdot \mathrm{g}^{-1} \mathrm{TL}\right)$ and higher than the CG value $\left(25.8 \mathrm{mg} \cdot \mathrm{g}^{-1} \mathrm{TL}\right)$ on the 56 th day $(\mathrm{P}<0.05)$. However, the opposite did not occur with the sum of $n-6$ FA, the quantities of which stayed at the same level as in the tissue of mice fed PG (192.8 to $\left.197.5 \mathrm{mg} . \mathrm{g}^{-1} \mathrm{TL}\right)$. The sum of $n-6$ decreased during FG feeding (233.7 to 200.4 mg. ${ }^{-1} \mathrm{TL}$ ) when compared with CG.

The $n-6 / n-3$ values were lower in muscle tissue in the PG and FG on the 7th day, decreasing significantly ( $\mathrm{P}<0.05$ ) from 28th days until 56th days, when compared to the CG. The average $n-6 / n-3$ ratio, according to Sugano and Hirahara (2000) and KrisEtherton et al. (2000), depends on diet duration.

\section{DISCUSSION}

In the present study, Swiss mice were used as experimental animals due to their numerous advantages, such as easy handling and the possibility of working simultaneously with several groups, in addition to their biological similarities with human beings. They are monogastric mammals and present metabolic routes similar to those of human beings (Leon, 2005).

The quantities of LNA, DPA and DHA were higher during all of the FG and PG treatments, as compared to the CG, in contrast to the values of n-6 PUFA LA and AA. This was because FG and PG had a greater concentration of LNA, which is a precursor of $n-3$ PUFA. These results agree with those reported by other authors showing that the inclusion of LNA sources in the diet of mice increased the concentration of the metabolites EPA and DHA in tissue (Tou et al., 2011).
The high dietary ratios of LA/LNA decreased the conversion of LNA into VLC-PUFA. Additionally, the ingestion of $n-6$ FA influences the concentration of $n-3$ FA in tissue. There is evidence that the amounts of $n-3$ PUFA can be improved by increasing their ingestion or by decreasing the ingestion of LA or by a combination of both, which is likely to be even more efficient (SanGiovanni and Chew, 2005).

Higher $n$-3 DPA and DHA values were found in the $\mathrm{PG}$ and FG due to their higher concentration of their precursor, LNA and its conversion in the liver induced by enzyme activity (Simopoulos, 2003; Martin et al., 2006). These higher values contributed to reduce the $n-6 / n-3$ ratio in relation to the CG values. In addition, diets poor in $n-3$ FA and with high $n-6 / n-3$ ratios may contribute to the development of many allergic, inflammatory and cardiovascular diseases (Tou et al., 2011).

DHA is an important FA in neonatal diet due to its role in the constitution, development and functioning of the head and retina (Esposito et al., 2008; Fernandes et al., 2011). It is also present in cell membranes and its deficiency is associated with visual impairment and head deformation (Igarashi et al., 2007). Muscle tissue showed the highest DHA synthesis during the entire experiment.

Diets with inadequate amounts of LNA cause an imbalance in $n-3$ and $n-6$ FA or deficient desaturation and elongation of FA. These factors influence the $n-3$ PUFA metabolism. In the presence of one or more of these factors, the production of these FA decreases (Moore et al., 1990). n-6 fatty acid intake influences tissue concentration of $n$-3 PUFA (Brenna et al., 2009).

n-3 PUFA-rich diets are important to prevent heart diseases. The presence of LNA in the diet may reduce arrhythmias (Ayalew-Pervanchon et al., 2007). Calder (2004) attributes this protective effect to the ability of $n$ 3 FA to reduce the plasma triglyceride level, blood pressure and platelet aggregation. n-3 FA are incorporated into myocardium cell membranes, potentially diverting the production of $n-2$ eicosanoids, which derive from arachidonic acid, to $n-3 \mathrm{FA}$, which derive from eicosapentaenoic acid and have vasodilating and platelet antiaggregation functions.

Animals treated with flaxseed and perilla mealenriched diet showed a lesser ability to incorporate Linoleic Acid (LA) and to synthesize Arachidonic Acid (AA). Animals treated with commercial feed did not show the same ability to incorporate and synthesize omega-3 series FA due to the low concentration of LNA.

\section{CONCLUSION}

The intake of perilla- and flaxseed meal-enriched diets by mice resulted in deposition of LNA and their 
metabolites EPA and DHA in muscle tissue. There was a significant increase of $n-3$ fatty acids and consequently a decrease in $n-6 / n-3$ ratio in the muscle tissue analyzed compared with commercial diet.

\section{ACKNOWLEDGMENT}

We are thankful to Capes for financial support.

\section{REFERENCES}

Asif, M., 2011. Health effects of omega-3,6,9 fatty acids: Perilla frutescens is a good example of plant oils. Orient. Pharm. Exp. Mef., 11: 51-59. DOI: 10.1007/s13596-011-0002-x

Ayalew-Pervanchon, A., D. Rousseau, D. Moreau, P. Assayag and P. Weill et al., 2007. Long-term effect of dietary \{alpha\}-linolenic acid or decosahexaenoic acid on incorporation of decosahexaenoic acid in membranes and its influence on rat heart in vivo. Am. J. Physiol. Heart Circ. Physiol., 293: 22962304. PMID: 17526653

Bagga, D., L. Wang, R. Eisner-Farias, J.A. Glaspy and S.T. Reddy, 2003. Differential effects of prostaglandin derived from $\omega-6$ and $\omega-3$ polyunsaturated fatty acids on COX-2 expression and IL-6 secretion. Proc. Natl. Acad. Sci., 100: 1751-1756. DOI: 10.1073/pnas.0334211100

Bligh, E.G. and W. J. Dyer, 1959. A rapid method of total lipid extraction and purification. Can. J. Biochem., 37: 911-917. PMID: 13671378

Brenna, J.T., N. Salem, A.J. Sinclair and S.C. Cunnane, 2009. Alpha-Linolenic acid supplementation and conversion to n-3 long-chain polyunsaturated fatty acids in humans. Prostag. Leuk. Essential. Fatty Acids, 80: 85-91. PMID: 19269799

Calder, P.C., 2004. n-3 fatty acids and cardiovascular disease: Evidence explained and mechanisms explored. Clin. Sci., 107: 1-11. PMID: 15132735

Calder, P.C., R. Albers, J.M. Antoine, S. Blum and R. Bourdet-Sicard et al., 2009. Inflammatory disease processes and interactions with nutrition. Br. J. Nutr., 101: S1-S45. DOI: $10.1017 / \mathrm{S} 0007114509377867$

Deckelbaum, R.J., T.S. Worgall and T. Seo, 2006. n-3 fatty acids and gene expression. Am. J. Clin. Nutr., 83: 1520S-1525S. PMID: 16841862

Esposito, G.I., G. Giovacchini, J.S. Liow, A.K. Bhattacharjee and D. Greenstein et al., 2008. Imaging neuroinflammation in Alzheimer's disease with radiolabeled arachidonic acid and pet. J. Nucl. Med., 49: 1414-1421. DOI: 10.2967/jnumed.107.049619
Fernandes, F.S., A.S. Souza, M.G.T. Carmo and G.T. Boaventura, 2011. Maternal intake of flaxseed-based diet (Linum usitatissimum) on hippocampus fatty acid profile: Implications for growth, locomotor activity and spatial memory. Nutrition, 27: 10401047. PMID: 21439792

Igarashi, M., J.C. DeMar, K. Ma, L. Chang and J.M. Bell et al., 2007. Upregulated liver conversion of alphalinolenic acid to docosahexaenoic acid in rats on a 15 week n-3 PUFA-deficient diet. J. Lipid. Res., 48: 152-164. PMID: 17050905

Innis, S.M., 2007. Fatty acids and early human development. Early Hum. Dev., 83: 761-66. DOI: 10.1016/j.earlhumdev.2007.09.004

James, M., R. Gibson and L. Cleland, 2000. Dietary polyunsaturated fatty acids and inflammatory mediator production. Am. J. Clin. Nutr., 71: 343S348S. PMID: 10617994

Joseph, J.D. and R.G. Ackman, 1992. Capillary column gas chromatographic method for analysis of encapsulated fish oils and fish oil ethyl esters: Collaborative study. J. AOAC Int., 75: 488-506.

Kim, H.Y., 2007. Novel metabolism of docosahexaenoic acid in neural cells. J. Biol. Chem., 282: 1866118665. DOI: $10.1074 /$ jbc.R700015200

Kris-Etherton, P.M., D.S. Taylor, S. Yu-Poth, P. Huth and K. Moriarty et al., 2000. Polyunsaturated fatty acids in the food chain in the United States. Am. J. Clin. Nutr., 71: 179S-188S. PMID: 10617969

Leon, L.R., 2005. The use of gene knockout mice in thermoregulation studies. J. Thermal. Biol., 30: 273288. DOI: 10.1016/j.jtherbio.2005.01.001

MacDonald-Wicks, L.K. and M.L. Garg, 2007. Incorporation of n-3 fatty acids into plasma and liver lipids of rats: Importance of background dietary fat. Lipids, 39: 545-551. PMID: 15554153

Martin, C.A., V.V. Almeida, M.R. Ruiz, J.E.L. Visentainer and M. Matsushita et al., 2006. Omega3 and omega-6 polyunsaturated fatty acids: Importance and occurrence in foods. Rev. Nut., 19: 761-770. DOI: 10.1590/S1415-52732006000600011

Moore, S.A., E. Yoder and A.A. Spector, 1990. Role of the blood-brain barrier in the formation of longchain $\omega-3$ and $\omega-6$ fatty acids from essential fatty acid precursors. J. Neurochem., 55: 391-402. DOI: 10.1111/j.1471-4159.1990.tb04150.x

NRC, 1995. Nutrient Requirements of Laboratory Animals. 4th Edn., National Academy Press, Washington, DC., ISBN-10: 0309051266, pp: 173. 
Perini, J.A.L., F.B. Stevanato, S.C. Sargi, J.E.L. Visentainer and M.M.O. Dalalio et al., 2010. Omega-3 and Omega-6 polyunsaturated fatty acids: Metabolism in mammals and immune response. Rev. Nutr., 23: 1075-1086. DOI: 10.1590/S141552732010000600013

Ratnayake, N. and C. Galli, 2009. Fat and fatty acid terminology, methods of analysis and fat digestion and metabolism: A background review paper. Ann. Nutr. Metab., 55: 8-43. DOI: 10.1159/000228994

Roberfroid, M., 2002. Functional food concept and its application to prebiotics. Dig. Liver Dis., 34: 105110. PMID: 12408452

SanGiovanni, J.P. and E.Y., Chew, 2005. The role of omega-3 long-chain polyunsaturated fatty acids in health and disease of the retina. Prog. Ret. Eye. Res., 24: 87-138. DOI: 10.1016/j.preteyeres.2004.06.002

Simopoulos, A.P., 2003. Importance of the ratio of omega-6/omega-3 essential fatty acids: Evolutionary aspects. World Rev. Nutr. Diet., 9: 1-22. DOI: $10.1159 / 000073788$

Sugano, M. and F. Hirahara, 2000. Polyunsaturated fatty acids in the food chain in Japan. Am. J. Clin. Nutr., 71: 189S-196S. PMID: 10617970
Tou, J.C., S.N. Altman, J.C. Gigliotti, V.A. Benedito and E.L. Cordonier, 2011. Different sources of omega-3 polyunsaturated fatty acids affects apparent digestibility, tissue deposition and tissue oxidative stability in growing female rats. Lipids Health Dis., 10: 179-179. DOI: 10.1186/1476-511X-10-179

Visentainer, J.V., 2012. Aspectos analíticos da resposta do detector de ionizacao em chama para esteres de acidos graxos em biodiesel e alimentos. Quim Nova, 35: 274-279. DOI: $10.1590 /$ S010040422012000200008

Wallace, F.A., E.A. Miles and P.C. Calder, 2003. Comparison of the effects of linseed oil and different doses of fish oil on mononuclear cell function in healthy human subjects. Br. J. Nutr., 89: 679-89. PMID: 12720588

Wurtman, R.J., 2008. Synapse formation and cognitive brain development: Effect of docosahexaenoic acid and other dietary constituents. Metab. Clin. Exp., 57: S6-S10. DOI: 10.1016/j.metabol.2008.07.007 